\title{
WORK ETHIC VALUES IN PAPPASENG AND ITS IMPLICATIONS FOR CAREER GUIDANCE IN SCHOOLS
}

Syahril $^{1}$

\begin{abstract}
This study aimed to reveal the work ethic values in the Bugis tribal pappaseng and the implications of work ethic values in pappaseng in career guidance. This type of research is descriptive qualitative research. The location of the study was conducted in Bone and Wajo District, South Sulawesi. Data collection is done through interviews with the number of respondents as many as four people consisting of two cultural people, one community leader and one academic. The results showed that Pappaseng reso, getteng, lempu, green tea idi'pa najaji, sipakainge, sipakatau, sipakalebbi, sipakainge malilu, mali siparappe, rebba sipatokkong, and siri were work ethic values in pappaseng which had implications for the development of career guidance services for the student.
\end{abstract}

Keywords: 21st Century Skills, MEA, Pappaseng, Work Ethics.

JOMSIGN: Journal of Multicultural Studies in Guidance and Counseling

Website: http://ejournal.upi.edu/index.php/JOMSIGN

Permalink: http://ejournal.upi.edu/index.php/JOMSIGN/article/view/6314

How to cite (APA): Syahril. (2018). Work Ethic Values in Pappaseng and its Implications for Career Guidance in Schools. JOMSIGN: Journal of Multicultural Studies in Guidance and Counseling, 2(2), 104-118.

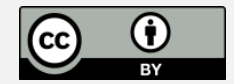

This is an open-access article distributed under the terms of the Creative Commons Attribution 4.0 International License, which permits unrestricted use, distribution, and reproduction in any medium, provided the original work is properly cited.

\section{INTRODUCTION}

The ASEAN Economic Community (AEC) was granted in December 2015 with members from Southeast Asian countries, namely Indonesia, Singapore, Malaysia, Brunei Darrussalam, Thailand, Myanmar, Cambodia. AEC was agreed in the 2012 Framework Agreement on Enhancing ASEAN Economic Cooperation (Saefuddin, \& Syah, 2014). This agreement aims to increase the competitiveness of ASEAN and can compete with China and India to attract foreign investment (Utomo, 2014). Through this AEC it creates a free market in the areas of the capital, goods and services, and labor. As a result of the AEC agreement, it has an impact on the free flow of goods and services for ASEAN countries, the free flow of investment, the free flow of capital, and the flow of skilled labor (Winanda, Ham \& Nugraha, 2015).

\footnotetext{
${ }^{1}$ STAIN Watampone; syahril@stainwatampone.ac.id
} 
One of the focuses of the AEC is the flow of skilled labor. The free flow of skilled workers can mean that all ASEAN citizens can go in and out to look for work without obstacles from the destination country. These skilled workers have the expertise, special skills, knowledge, and expertise in their fields that can come from tertiary graduates or are supported by informal abilities obtained from informal education institutions such as foreign language courses or other competency courses, as well as from work experience (Evienia, Aldi \& Madhyaratri, 2014). Workers from AEC countries who have higher work competencies will certainly have wider opportunities to gain economic benefits in the AEC (Selegi, 2015).

Thus, the flow of skilled workers will be a formidable challenge for the Indonesian people, so that the government and stakeholders need to prepare themselves to face the influence of the free flow of labor if they do not want the Indonesian nation to become an invasion of foreign skilled workers and the Indonesian people to be spectators in their own country. This is where the role of education and educators in dealing with the AEC must be increased to prepare workers who are ready to enter the workforce, both formally and informally, both domestically and ASEAN to prevent the flood of skilled workers from outside (Fatkuroji, 2014)

Counselors or BK teachers as educators have an important role in preparing skilled workers through guidance and counseling services in the field of career guidance to students in schools (Arifah, 2015). Through career guidance 1) students will be equipped with core skills (core work skills needed by all types of jobs and positions that must be owned by someone to be successful and produce quality performance (Buchori, 2014), 2) students will be able to have a positive attitude towards the world of work. (Ministry of National Education 2007). A positive attitude means a person must work diligently, honesty, loyalty to achieve the best in every aspect of his work. This attitude is usually called the work ethic (Chester, 2012). According to Ramli (2014), the work ethic needs to be had by every young generation, especially in dealing with the invasion of foreign workers in Indonesia because in the work ethic there is a very strong spirit to do things optimally better. These efforts to achieve the quality of work as perfect as possible.

Work ethic is a cultural norm that advocates being responsible for the work someone does and is based on the belief that work has intrinsic value. 
Work ethic is owned by individuals and groups of people in the community. (Hill, \& Petty, 1995).

Initially, the work ethic refers to the spirit of capitalism, as is the spirit that is in the work ethic of the protestants, and also refers to the ethics of the ascetics of the protestant, which is a doctrine that rewards continuous and consistent work professionalism that upholds willingness/sincerity (sincerity) Bogt., Raaijmakers \& Wel, 2005). But now, the construct of work ethic is associated with the process of valuing work outside the religious context. Ethics outside this religious context evaluates the work ethic in terms of morality or normative values. A job will be considered good and morally virtuous if the job is a job that tends to be desirable and is a main element/element in life normatively and does not necessarily have to be morally good (Czerw, Agnieszka \& Grabowski, 2015).

Work ethic is formed by various habits, cultural influences, and value systems (religion and belief) which he believes (Hill, 1997). The influence of culture, especially local values, greatly influences the work ethic of a nation. This can be seen from the success of the Japanese in the economic and technological fields. building a nation in various sectors is based on the foundation of its cultural background (Syamsuddin, 2010).

The Japanese have a Bushido work ethic which is considered as an important factor behind the success of the Japanese economy on the world stage (Ingsih, 2011). Bushido's work ethic outlines seven principles, namely: 1) $G i$ (the right decision is taken with the right attitude based on truth); 2) $Y u$ (brave and chivalrous), 3) Jin (generous, loving and kind towards others), 4) $R e$ (being polite, acting right), 4) Makoto (being sincere sincerely, being sincere with truly and unconditionally, 5) Melyo (maintaining honor, dignity, and glory), 6) Chugo (serving and loyal) (Ingsih, 2011).

In addition to the Japanese, the Indonesian people also have a culture that contains work ethic values. Among others are owned by the Madurese and the Bugis. The value of the work ethic of the Madurese. Some words in the Madurese language that have meanings and meanings of other work ethics: 1) Bharenteng (very active), that is, Madurese show a diligent nature and sincerity to work, 2) Burning colpe '(working hard), tenacity working hard for nyare kasap (looking for a bite of rice) one of the characteristics of the Madurese at work, 3) Nyaronen (effort endeavored), Madurese are willing to do any work that is of halal importance, 4) Jhak-ajhak (cooperation), in working Madurese 
always work together with others in doing something (Rifai in Faraby \& Faiza, 2014).

Likewise, the Bugis tribe found in South Sulawesi, work ethic values are found in the Pappaseng culture. Pappaseng is a message from parents (Bugis ancestors) to their children and grandchildren which contain instructions and advice in living life in the community well (Punagi, 1983).

The results of the study of various kinds of literature both through articles and research results, found some work ethic values in Pappaseng, namely: 1) Reso (hard work), 2) Getteng (Firm Establishment), 3) Slab (Honesty), 4) Tea Tamakua idipanajaji, 5) Sipakainge, Sipakatau, and sipakalebbi, 6) Malilu Sipakainge, Mali Siparappe, Rebba Sipatokkong and 7) siri '(self-esteem) (Abdullah, 2014; Amir \& Dalle, t.th; Abbas, 2013).

Reso or hard work means that the Bugis must work hard to achieve something to get mercy from Him. This is found in the phrase "Resopa natinulu, malomo naletei Pammase Dewata" (only with diligent hard work often becomes a bridge of Divine Grace) (Kesuma, 2012). Getteng (firmness of establishment). the meaning is faithful to the conviction, tough in the establishment, tightly holding something and staying obedient to every belief that he believes. Lempu (Honesty) means patient, sincere, true, good and fair. As opposed to the word wicked, betrayal, persecution and deception. Tea Tamakua idipanajaji which means a person's success depends on himself, what he chose in the past time the results he will feel at this time.

Sipakainga, Sipakatau, and sipakalebbi. Attitude implies that to achieve success it is necessary to relate to fellow human beings because success cannot be achieved without the help and interaction with people around others including business relationships and colleagues. Malilu Sipakainge, Mali Siparappe, RebbaSipatokkong means that humans should help one another not to knock each other down but instead support one another and remind one another among human beings because towards success there must be challenges.

Siri (shame and pride). In the view of the Bugis, so-called "humans" are those who have shame. In the Buginese language, there is the expression: "Iyami Riaseng Tau Taroi Siri Alena". The translation is what is called a human being who puts shame in himself. And "Siri-Emi Nariaseng Tau". It means that we are just ashamed so we are called humans. The word "siri" also means "dignity, dignity, and behavior. For people, Bugis siri is also an important driver of social life and are drivers of social achievement in the community (Pelras, 2006). 
Various research results about the work ethic of Bugis culture were conducted by Yulianti (2014). As a result, Bugis' cultural values related to work ethic, which is hard work (reso) and siri, are very influential on the success of the Bugis business activities in Nunukan. Another study was conducted by Nahari (2012) who examined the cultural value of the Bugis tribe that influenced the work ethic in Tegal. The result is that siri is a cultural value that influences the work ethic of the Bugis community in Tegal.

The results of the above study can be interpreted that cultural values are something that needs to be applied to the younger generation, especially students in schools in improving the work ethic both when studying and when they have worked. The inculcation of values embodied in the local culture is expected to be able to shape students who have a character that can survive amid the era of globalization and a sense of love for their local culture so that it is not eroded by the swift currents of globalization (Syarif et al, 2016).

\section{METHOD}

This type of research is a qualitative descriptive study. The location of the study was carried out in Kab. Bone and Kab. Wajo South Sulawesi. Data collection is done through interviews. The number of respondents was three people consisting of two cultural figures and one community figure. Data analysis was performed by data collection, data reduction, and concluding.

\section{RESULTS AND DISCUSSION}

\section{Work Ethic Values in Pappaseng}

Pappaseng is a pearl of local wisdom (local genius) that holds the Bugis tribe in their lives and is passed down from generation to generation (Jemmain, 2011). Pappaseng contains a variety of advice or advice that can be used as a guide in dealing with various problems of life, both worldly and ukhrawi life. In Pappaseng, it was found, among others, instructions on good governance, character education and religious moral values (Jemmain, 2011).

As a value that is held, Pappaseng has a strategic role in realizing the value of an immanent work ethic with the existence of the Buginese tribe in a well-known historical track with a high work ethic in government, commerce, agriculture, and the like. Pappaseng is a neat fusion of theocentric religious normativity with anthropocentric culture. In its development, the values of the 
work ethic in Pappaseng can be understood as an effort to improve the intention to start an activity (Bausat, 59 years old) The same thing was expressed by Muh. Idris Ibrahim that pappaseng with the encouragement of its work ethic requires humans to work by first improving their intentions, the Bugis tribe works to follow the message of parents and must be following religious teachings by always praying (Muh. Idris Ibrahim, 66 years). By holding fast pappaseng, the Bugis are always highly motivated in living their lives so that it can be implemented into the business or deeds (Sikki, 1998: 6-7).

The data above shows that Pappaseng always unites universal values which are recognized as general truths which in this case is work ethic. Humans are khalifatullah on earth who are always required to have high morale to achieve what has been aspired. The same thing is also illustrated by Muhammad $\mathrm{R}$ that the values of morale in Pappaseng are the handle of the Bugis tribe before starting an activity with high optimism about the success of what will be done. The thing illustrated in pappaseng is "makkellu pempekko mulao, mabbulu rompeko mulisu" which means to go empty and contain or in other words it is necessary to have a thorough calculation of the success of the activities carried out by always hoping for the grace of Allah SWT. as in the pappaseng they hold, namely "resopa temmangingi namalomo naletei pammase dewata" which means only an enterprising and relentless endeavor that will ease the grace of Allah SWT. (Muhammad R, 69 years old)

\section{Reso}

Reso is a business that the Bugis tribe verbalizes in the phrase "resopa temmangingi" which means the business that is sustainable and tireless (Muh.Idris Rahim, 66 years old). Reso in its position as a translation of the values of the work ethic through efforts to find various dimensions of happiness that are pragmatic does not mean then deny the position of God as a source of fortune. Therefore, the Bugis consider that reso is only the cause of the coming of sustenance in various forms due to the grace of Allah. remains the final determinant. It is not surprising then if reso is considered as one of the conditions for one's success in his life (Bausat, 59 years old). The same thing was expressed by Muhammad $\mathrm{R}$ that reso is the key to the arrival of fortune (Muhammad R, 69 years old). The position of Reso as an applicative framework of Pappaseng which contains the values of the work ethic contains the urge to always make every effort while remaining loyal to Him. This can be seen from the pappaseng "Ajaq mumaeloq ribettang makkalêjjaq ricappaqna letengnge ". 
That is, do not want to be preceded setting foot at the end of the footbridge. Pappaseng has the meaning that the Bugis in trying to work with the maximum and intelligence to see business opportunities. This shows that in the effort required attention and competitive hard work (Abbas, 2013).

Besides, the Bugis have a principle that is always held in the work of "lebbimoi mate maddarae rather than mate makkapoppang (malupue). This means that it is better to die bleeding (fight in the war) than to die of hunger.

The principle must live within the Buginese man to motivate him to work hard to find a decent living. "Bloody death" is interpreted positively as the maximum effort of humans in seeking halal fortune while "starving to death" is interpreted as a symbol of lazy people who are just waiting for helping and helping from others without trying (Rusli, 20015 years old).

\section{Getteng}

Getteng is a firm stand. Concerning work ethic, getteng requires consistency and is not easy to change. The intention and commitment that has been built from the beginning must be maintained (Muh.Idris Rahim, 66 years). Getteng's illustration as the consistency of what is believed to be intentions and commitments is also justified by Bausat who illustrates that assertiveness in work is a necessity and should not be changed without a strong reason (Bausat, 59 years old). Reflecting on the implementation of the law as an analogy, it can be found that the law with its strict normativity side turns out to have a dimension of flexibility as long as there is an urgent situation, so does the getteng analogy as an understanding of the value of the work ethic in it that can follow developments that exist not against the principle just the thing. The limitation of flexibility in the getteng pappaseng was illustrated by Muhammad $\mathrm{R}$ who argued that the firmness of the establishment in getteng was related to principles that were believed and were not easily deceived by the persuasion of Satan (Muhammad R, 69 years old).

Therefore, the implementation of getteng in daily life is very important to apply especially to the younger generation so that later they will become human beings who have the principle of commitment and consequence not easily oscillating from various tempting influences, especially on things that can destroy in life himself and others (Nurnaningsih, 2015). Furthermore, Nurnaningsih (2015) revealed that having a getteng attitude was reflected in four things, namely respecting his promise-consistent with his words; not 
canceling agreed-upon matters that respect the vow; if you speak rationally; and a sense of responsibility encourages completing everything he does).

\section{Lempu}

Lempu is honesty. As an applicative framework of Pappaseng which contains work ethic values, the Bugis in working for a living always plant plates as a guideline for building sacred intentions. A little or a lot of income earned with plates, at least, will bring blessing (Muh.Idris Rahim, 66 years old). With the same editorial, Bausat also illustrates that the large capital plates in building positive assessments of people around because the plates can lead to an applicative framework for what is said to be what is done (Bausat, 59 years old). As for Muhammad R illustrates that the plates have axiological implications in the form of increasingly positive relationships with people around because honesty (plates) adds to the sympathy of others (Muhammad R, 69 years) Pappaseng plates are living capital of the Bugis community that must be maintained, in and in any position he is active including in this case work whether as an employee or an entrepreneur. Honesty is manifested in the form of behavior and speech, both to oneself and to others (Hamid, 2003)

In some Bugis realms, some pasengs were set up which called for the need to be honest (Lempu). This can be seen in the excerpt "Yes decengnge tuwimmompu ri lempue, thank God Almighty naelori toi densa appearance. This means that the cause of goodness is in honesty, pitied by God and loved by fellow human beings. (Abidin, 1983). Pappaseng implies that honesty is important for the source of goodness. That way people will be pitied by God and loved by fellow human beings. Conversely, if someone is not honest, he will be punished by Allah and hated by humans. therefore, Buginese humans must not cheat, wickedness, corruption in their daily activities including working both as employees and as entrepreneurs. Lempu must be accompanied by taqwa to Allah SWT, which is an honest attitude in behavior and speech, both to oneself and to others (Hamid, 2015).

\section{Tea Tamakua Idi'pa Najaji}

Tea tamakua idi'pa najaji can be understood as direct participation in the work involved (Bausat, 59 years) Meanwhile, Muh. Idris Ibrahim illustrates that pappaseng tea tamakua idi'pa najaji implies that the Bugis do not like to depend on others. They dare to be independent in their activities (Muh.Idris Rahim, 66 years old). The value of the work ethic in pappaseng tea tamakua idi'pa najaji does not mean that the Bugis deny the management principle as an effort to 
maximize all the potential that exists, especially those around to achieve certain goals. Muhammad R stated that sometimes the Bugis tribe requires work to be done alone and sometimes can be represented by others (Muhammad R, 69 years old). Pappaseng tea tamakua idi'pa najaji encourages them to involve themselves actively and proportionally in a work that has implications for their work ethic.

\section{Sipakainge, Sipakatau, Sipakalebbi}

Sipakatau, supakainge, sipakalebbi are pappaseng that contain strong work ethic values. In it, there is a moral message to do good things like to improve/enhance others. One must advise one another, respect one another and glorify one another. What is the use of a successful business if it harms others (Muh.Idris Rahim, 66 years). In line with this, Bausat illustrates that pappaseng sipakatau, supakainge, sipakalebbi strengthen the work ethic of the Bugis tribe because humans have an instinct for it where colleagues must remind each other (sipakainge), must respect each other (sipakatau) and mutually glorify each other (sipakalebbi ) (Bausat, 59 years old) This mutual respect becomes a work ethic contained in Pappaseng to further inspire the Bugis in their careers in various fields. Adding to this, Muhammad R mentioned that the Sipakatau, supakainge, and sipakalebbi pappaseng are very well known as $3 \mathrm{~S}$ and are being held in the hands of the Bugis (Muhammad R, 69 years).

Pappaseng sipakatau shows that Bugis culture positions humans as God's creatures that are noble and therefore must be respected and treated well (Sharif at al, 2017) so that in social life, one should look at humans like humans fully in any condition. In essence, mutual respect between human beings without seeing him poor or rich or under any circumstances, anytime and anywhere without distinguishing ethnicity, religion and social status (Maida, 2016) including doing work activities.

Pappaseng sipakainge, means that the Bugis must remind one another. As a human being full of various shortcomings. Therefore the need to remind each other and also provide input in the form of criticism and advice to each other. Sipakainge attitude is an attitude possessed by every human being for the sake of life balance (Maida, 2016). While pappaseng silapakalebbi, can not be separated from as an ordinary human being can not be separated with a conscience, which always likes everything that smells of beauty both in the form of goods to words of praise. Recognizing the strengths of others as well as one's shortcomings, and accepting all of these conditions with an open heart and 
covering each other's shortcomings or hand in hand in all activities is a form of respect for one another (Razak, 2015).

\section{Malilu Sipakainge, Mali Siparappe, Rebba Sipatokkong}

Pappaseng malilu sipakainge, mali siparappe, rebba sipatokkong can be understood as the spirit of togetherness of the Bugis tribe which is one of the drivers of the formation of a work ethic between them as a community with a strong entity. The work ethic value in the pappaseng can be understood from what is conveyed by Bausat that remind each other if they are forgotten (malilu sipakainge), help each other (mali siparappe), and mutually support/awaken (rebba sipatokkong) can increase fortune because in it formed a pattern of mutual filling in the gaps of each community member over the other (Bausat, 59 years). Empirical-historical facts have proven that the Bugis work abstinence-only for their interests, but still pay attention to their colleagues, their families. There are among family or colleagues in the deterioration of morals/attitudes they are aware of each other when friends fall in deterioration of their efforts to help and inspire/encourage (Muh.Idris Rahim, 66 years). Furthermore, Muhammad R stated that the spirit of togetherness in the framework of Pappaseng Malilu Sipakainge, Mali Siparappe, Rebba Sipatokkong with mutual, caring, and fostering is a form of investment for those who do it because it could be sustenance for them to be entrusted by Allah Almighty. in others (Muhammad R, 69 years). Pappaseng Malilu Sipakainge, Mali Siparappe, Rebba Sipatokkong gave messages of the importance of help from others and their mutual relations. That is, the success of life will be easily achieved with the help of others. A realization that humans are social creatures who always need help from others.

\section{Siri}

Siri 'is a pappaseng that has a work ethic value because people who have siri' in their lives are very challenged to do wrong actions. After all, it involves their self-esteem so as far as possible will avoid cheating behavior at work (Bausat, 59 years old). It is not surprising then that papapseng siri 'is highly respected by the Bugis in building a work ethic at their career path. Violation of the values believed, both in theocentric religious normativity with anthropocentric culture, implications for self-esteem and become one of the barometers of weakening siri 'so commonly called "makurassiri". Responding to this, Muh. Idris Rahim also said that the Bugis work upholding siri '(self-esteem/shame) even willing to sacrifice their lives if it is related to shame (siri napacce) (Muh.Idris Rahim, 
66 years). Meanwhile, Muhammad R illustrates that concerning the value of the work ethic in Pappaseng Siri, the Bugis are very diligent in their work to achieve what they aspire to. The shame of going home without success, especially those who go abroad, there are manifestations of pappaseng siri '(Muhammad R, 69 years). Consequently, they are very motivated to work with a high work ethic and remain in the corridor of moral values because returning home empty-handed or stumbling on legal issues is a risk to their siri (selfesteem). This is consistent with Rusli's (2015) opinion that siri 'is useful for the development of civilization in a global society because it functions as a motivator, social control, sense of responsibility and social dynamism. Siri'i is also a self-esteem bet so that self-esteem must be raised through hard work, achievement, pioneering spirit and success-oriented attitude.

Siri 'as the core of Bugis culture has the potential to be able to improve student achievement, because siri' is a view of life that aims to increase dignity, dignity, and self-esteem, both as individuals and as social beings (Syarif et al, 2016). Siri 'is widely used by Bugis nomads. He will be ashamed to return home if he succeeded in achieving what he wanted. Siri, in this case, is interpreted as persistence in working for success to raise the family's honor (Hamid, 2015)

\section{Implications of Work Ethic Values in Pappaseng for Career Guidance in Schools}

The rapid development of science and technology has a very big impact on the field of human life, especially in the field of education. In this 21 st century, the digital age, education is increasingly important to ensure students have the skills to learn and innovate, the skills of using technology and information media, and can work, and survive by using life skills (Murti, yr.)

Anticipating this the government through the Ministry of Education and Culture (2017), stated that students in schools are required to have skills called 21st Century skills, which consist of 1) Critical Thinking Skills and ProblemSolving Skills, 2) Communication Skills, 3) Creativity and Innovation, 4) Collaboration. These skills are used by students in learning and working as soft skills.

The development of these skills is carried out through learning by the field of study teachers through their respective subjects. Learning in each subject is related to competencies and contexts that must encourage students to have thinking skills from simple Low Order Thinking Skills (HOTS) to higher-order thinking processes Higher Order Thinking Skills (HOTS) (Kemendikbud, 2017) 
Development of 21st-century skills can also be done by BK teachers or counselors in schools through guidance and counseling services, especially in the field of career guidance. The aim of guidance and counseling in the career field is to equip students with various skills needed in the future including 21 stcentury skills.

In addition to helping students to have 21 st-century skills, the counselor can also equip students with a positive attitude towards work, namely an attitude of hard work, responsibility, high motivation, and loyalty in achieving every aspect of their work. This attitude is called work ethic. The work ethic can be sourced from the local culture used by the local community to achieve success.

The work ethic in Pappaseng as a cultural value of the Bugis tribe can be given to students of Bugis ethnicity through career guidance services at school. Pappaseng Reso, Getteng, Lempu, Tamakua Idiji Tea Najaji, Sipakainge, Sipakatau, Sipakalebbi, Malilu Sipakainge, Mali Siparappe, Rebba Sipatokkong, and Siri have been applied by the Bugis in achieving their goals. There is a lot of evidence that shows that the Bugis have become successful traders, sailors, politicians, and even the Vice President by applying Pappaseng in their work.

\section{CONCLUSION}

The work ethic values in Pappaseng are values based on local wisdom (local genius) that are deeply rooted in the life of the Bugis tribe. Pappaseng Reso, Getteng, Lempu, Tamakua Idiji Tea, Najaji, Sipakainge, Sipakatau, Sipakalebbi, Malilu Sipakainge, Mali Siparappe, Rebba Sipatokkong, and Siri 'encourage them to always improve work ethic for career achievement in various fields of work. The values of work ethic in Pappaseng can be given to students to develop a positive attitude towards work ethic through career guidance services at school.

\section{REFERENCES}

Abbas, I. (2013). Pappaseng: Kearifan lokal manusia bugis yang terlupakan. Sosiohumaniora, 3(15), 272 - 284

Abdullah, E. (2014). Mengungkap rahasia etos kerja orang bugis. Jakarta: Kompasiana. 
Abidin, A. Z. (1983). Arti lontara sulawesi selatan untuk sejarah hukum hukum Indonesia dalam persepsi orang bugis-makassar tentang hukum, negara, dan dunia luar. Bandung: Alumni.

Amir, J., \& Dalle, A. (n.y). Pappaseng Alempureng sebagai Sarana Pengendalian Diri pada Masyarakat Bugis. Makalah. Universitas Negeri Makassar

Kesuma, A. I. (2012). Moral ekonomi (Manusia) bugis. Makassar. Rayhan Intermedia.

Arifah, Diyah Fatwati. (2015) Peran Layanan Bimbingan \& Konseling untuk Mempersiapkan Tenaga Kerja Berkualitas Masyarakat Ekonomi ASEAN (MEA). Seminar Nasional Bimbingan Dan Konseling "Profesi BK di Era Masyarakat Ekonomi ASEAN (MEA)" Universitas Muhammadiyah Malang, 170-176

Buchori, Sahril. (2014). Program Bimbingan Karier Untuk Peningkatan Core Work Skills Mahasiswa (Studi Eksperimen Kuasi terhadap Mahasiswa Semester Akhir Program Studi Manajemen Universitas Pendidikan Indonesia). Tesis. UPI: Bandung.

Bogt, Tom ter., Raaijmakers, Quinten, \& Wel, Frits van. (2005) Socialization and development of the work ethic among adolescents and young adults. Journal of Vocational Behavior (66) 420-437

Chester, Eric. (2012). Reviving Work Ethic: A Leader's Guide to Ending Entitlemeny and Restoring Pride in thne Emerging Workforce. Greenleaf Book Group Press

Czerw, Agnieszka \& Grabowski. (2015). Damian Work Attitudes and Work Ethic as Predictors of Work Engagement among Polish Employees.Polish Psychological Bulletin, 4. (46) 503-512. DOI - 10.1515/ppb-2015-0057

Depdiknas. (2007) Rambu-Rambu Penyelenggaraan Bimbingan Dan Konseling Dalam Jalur Pendidikan Formal. Jakarta: Direktorat Jenderal Peningkatan Mutu Pendidikan dan Tenaga Kependidikan 
Evienia, Benedicta P., Aldi, B. Elnath \& Madhyaratri, Astri. (2014) Pandangan Pelaku Pendidikan di Universitas Terhadap Pemberlakuan Masyarakat Ekonomi ASEAN 2015. Bina Ekonomi Majalah Ilmiah Fakultas Ekonomi Unpar. 2(18), 105-116

Faraby, Muhammad Ersya \& Faiza, Siti Inayatul. (2014). Etos Kerja Pedagang Etnis Madura di Pusat Grosir Surabaya Ditinjau dari Etika Bisnis Islam. JESTT, 1(3), 178-193

Fatkuroji. (2014). Kesiapan Pendidik dan Tenaga Kependidikan Dalam Menyonsong Masyarakat Ekonomi ASEAN (MEA). Jurnal Idaroh, 1 (1), 101 - 114

Hill, Roger B. \& Petty, Gregory C. (1995) A New Look at Selected Employability Skills: A Factor Analysis of the Occupational Work Ethic. Journal of Vocational Education Research, 4(20),

Hill, Roger B.. (1997). Demographic Differences in Selected Work Ethic Attributes. Journal of Career Development, 1(24), 3-24

Ingsih, Kusni. (2011). Menerapkan Etos Kerja Profesional Dalam Meningkatkan Kinerja. Seminar Nasional Teknologi Informasi \& Komunikasi Terapan. ISBN 979-26-0255-0

Jemmain. (2011) Aktualisasi Nilai Pappaseng Dalam Rangka Pembangunan Karakter Bangsa (Actualization Pappaseng Value in Building Character Nation). Sawerigading, ,17(3): 321-334

Lanny Ramli. Meningkatkan Etos Keja di Era MEA. http://news.unair.ac.id

Maida, Nur (2016). Pengasuhan Anak dan Budaya 3S (Sipakatau, Sipakainge dan Sipakalebbi) Di Perkotaan. Seminar Nasional "Pendidikan Ilmu-Ilmu Sosial Membentuk Karakter Bangsa Dalam Rangka Daya Saing Global tanggal 29 Oktober 2016

Nahari, M. Fernandi. (2012) Nilai Budaya Suku Bugis Yang Mempengaruhi Etos Kerja. thesis, Universitas Negeri Semarang.

Nurnaningsih. (2015). Asimilasi Lontara Pangadereng dan Syari'at Islam: Pola Perilaku Masyarakat Bugis-Wajo Al-Tahrir, 1(15) : 21-41

Pelras, Christian. (2006). Manusia Bugis. Terjemahan. Jakarta: Nalar dan Kerja sama dengan Forum Jakarta-Paris

Punagi, A. Abu Bakar, Dkk. (1983). Pappaseng (Wasiat Orang Tua Dulu). Ujung Pandang: YKSS. 
Saepudin, Encep \& Syah, Wage F. (2015). Masyarakat Ekonomi Asean (Mea) Ditinjau Dari Perspektif Islam (Pendekatan Surat Al Jumuah (62) AYAT 10 - 11).. Seminar Nasional Hasil - Hasil Penelitian dan Pengabdian LPPM Universitas Muhammadiyah Purwokerto, 6-15

Rusli, Muh. (2015) Impelementasi Nilai Siri’ Napacce dan Agama Di Tanah Rantau; Potret Suku Bugis-Makassar Di Kota Gorontalo. Jurnal al-Asas, 3(2), 133-148

Selegi, Susanti Faipri (2015) Evaluasi Peran Perguruan Tinggi Dalam Menghadapi Masyarakat Ekonomi ASEAN (MEA). Seminar Pendidikan Nasional Peluang Dan Nurnaningsih. (2015). Asimilasi Lontara Pangadereng dan Syari'at Islam: Pola Perilaku Masyarakat Bugis-Wajo Al-Tahrir, 1(15) : 21-41

Sikki, Muhammad. (1998). Nilai dan Manfaat Pappaseng dalam Sastra Bugis. Jakarta: Pusat Pembinaan dan Pengembangan Bahasa, Departemen Pendidikan dan kebudayaan.

Tantangan Dunia Pendidikan Dalam Era Masyarakat Ekonomi ASEAN (MEA), $1735-1750$

Syamsuddin, M. Mukhtasar (2010). Pendekatan Fenomenologis dalam Studi Perbandingan Etos Kerja Manusia Bugis-Makassar dan Bangsa Jepang. Jurnal Filsafat, 2.(20), 183-196

Syarif, Erman, Sumarmi., Fatchan. Ach., \& Astina I Komang. (2016) Integrasi Nilai Budaya Etnis Bugis Makassar Dalam Proses Pembelajaran Sebagai Salah Satu Strategi Menghadapi Era Masyarakat Ekonomi ASEAN (MEA). Jurnal Teori dan Praksis Pembelajaran(10) IPS , 18-31

Utomo, Pudjo. (2014). Kesiapan Sumber Daya Manusia (Tenaga Kerja) Bidang Konstruksi Di Indonesia Menghadapi Masyarakat Ekonomi ASEAN. Jurnal Ilmiah Ilmu Hukum QISTIE, 2(7), 85-97

Winanda, Raynaldo Vea., Ham, Devin \& Nugraha, Paulus (2015). Analisis Kesiapan Sumber Daya Manusia Pada Kontraktor Di Surabaya Menghadapi Masyarakat Ekonomi ASEAN. Jurnal Dimensi Pratama Teknik Sipil, 2(4), 1-8

Yulianti, Rahmani Timorita. (2014) Pengaruh agama dan budaya terhadap etos kerja pebisnis muslim suku bugis di Kab. Nunukan. Millah,1 (14), 1-20 